Jerzy Gaul

\title{
„Upojenie wolnością" i społeczne oraz gospodarcze uwarunkowania odbudowy państwa polskiego w czasie rządów Naczelnika Państwa Józefa Piłsudskiego 1918-1922*
}

\begin{abstract}
„A jednak, czy jest kraj, który by przez te cztery lata na większe narażony był niebezpieczeństwa i większe ponosił trudy i ciężary, niż Polska?”
\end{abstract}

(Józef Piłsudski ${ }^{1}$

\begin{abstract}
Abstrakt: Po odzyskaniu wolności po 123 latach niewoli Polacy byli „upojeni wolnością”, jak powiedział Józef Piłsudski. W cieniu tej euforii zachodziły na ziemiach polskich ważne procesy społeczne i gospodarcze oraz występowały istotne zagrożenia zewnętrzne i wewnętrzne, które warunkowały odbudowę państwa polskiego w czasie rządów Tymczasowego Naczelnika Państwa (11 XI 1918 - 26 I 1919) oraz Naczelnika Państwa (26 I 1919 - XII 1922).
\end{abstract}

Słow a klu c z ow e: Józef Piłsudski, racja stanu, państwo polskie, społeczeństwo, gospodarka.

\footnotetext{
* Jest to rozszerzona wersja referatu w języku angielskim, pt. „ "Intoxicated with freedom» and the social and economic conditions for the construction of the Polish State 1918-1922", wygłoszonego 11 VI 2018 r. na konferencji „1918 e gli anni successivi: economia, finanza e strutture nell'area Adriatico-Danubiana” (,1918 and afterwards: economy, finance and the structures in the Danube-Adriatic region”), zorganizowanej przez Austriacki Instytut Historyczny (l'Istituto storico austriaco) i Akademię Rumuńską (l’Accademia di Romania) 11-12 VI 2018 r. w Rzymie.

1 J. Piłsudski, Pisma zbiorowe, t. V, Warszawa 1937, s. 276, Przemówienie na bankiecie w Katowicach, 28 VIII 1922 r. W podobnym duchu rozmawiał w styczniu 1919 r. ze Szkotem Thomasem Barclayem: Polski Garibaldi, „Niepodległość” 1986, t. XIX, s. 228-229. J. Pajewski, Budowa Drugiej Rzeczypospolitej 1918-1926, wyd. 2, Poznań 2007, s. 36-37.
} 
Abstract: After regaining their freedom after 123 years of subjection, Polish people were "inebriated with freedom", as Józef Piłsudski said. It was in the shadow of this euphoria that important social and economic processes occurred, together with grave internal and external threats that conditioned the restoration of the Polish state under the Provisional Chief of State (11 November 1918 - 26 January 1919), and the Chief of State (26 January 1919 - December 1922).

Key w or d s: Józef Piłsudski, raison d'état, Polish State, society, economy.

\section{Wstęp}

Po zakończeniu Wielkiej Wojny i upadku imperiów austro-węgierskiego, niemieckiego i rosyjskiego doszło w Europie Środkowo-Wschodniej do przemian politycznych i powstania wielu państw narodowych, w tym także Rzeczypospolitej Polskiej2. Odzyskanie wolności po 123 latach niewoli stanowiło dla Polaków wydarzenie niezwykłe. Nic dziwnego, że byli „upojeni wolnościa”. Tak określił stan swoich rodaków Józef Piłsudski: „W całej pełni rozkoszujemy się odzyskanymi prawami, gdy wspominamy lata cierpień, któreśmy dopiero co przeżyli”3.

Co jednak działo się w cieniu tego „upojenia”? Jak wyglądały procesy społeczne i gospodarcze na ziemiach polskich po uzyskaniu niepodległości, w jaki sposób warunkowały odbudowę państwa polskiego? Jak długo trwało „upojenie wolnością, o którym mówił Naczelnik Państwa, i czy wystarczyło do przezwyciężenia zagrożeń zewnętrznych i wewnętrznych? Niebezpieczeństwa zewnętrzne wynikały z walk o granice państwa i oddziaływań ideologii bolszewickiej. Zagrożenia wewnętrzne brały się z chaosu, podziałów społecznych i trudności gospodarczych ${ }^{4}$.

\footnotetext{
${ }^{2}$ Na gruzach imperium habsburskiego, oprócz Polski, powstały niemiecka Austria (od 1919 Republika Austrii), Czechy, Węgry, państwo Serbów, Chorwatów i Słoweńców (od 1929 Jugosławia). W. Brauneder, Die Verfassungssituation 1918: ein Staat entsteht, ein Staat geht unter, w: Österreich. 90 Jahre Republik. Beitragsband der Ausstellung im Parlament, red. S. Karner, L. Mikoletzky, Innsbruck-Wien-Bozen 2008, s. 23.

${ }^{3}$ J. Piłsudski, op. cit., t. V, s. 276.

${ }^{4}$ Zagadnienia te maja bogatą literature przedmiotu. Zob. m.in.: Z. Landau, J. Tomaszewski, Gospodarka Polski międzywojennej 1918-1923, t. I: W dobie inflacji 1918-1923, Warszawa 1967; A. Ajnenkiel, Od rzqdów ludowych do przewrotu majowego. Zarys dziejów politycznych Polski 1918-1926, Warszawa 1978; Polska odrodzona 1918-1939. Państwo, społeczeństwo, kultura, red. J. Tomicki, Warszawa 1982; A. Friszke, O ksztatt niepodlegtej, Warszawa 1989; J. Pajewski, Budowa Drugiej Rzeczypospolitej...; K. Badziak, W oczekiwaniu na przełom. Na drodze od odrodzenia do załamania państwa polskiego listopad 1918 - czerwiec 1920, Łódź 2004; H. Bartoszewicz, Dzieje pierwszych dwudziestu miesięcy II Rzeczypospolitej czy monografia gabinetu Leopolda Skulskiego?, „Dzieje Najnowsze” 2008, nr 2, s. 134-145; M. Leczyk, Druga Rzeczpospolita 1918-1939. Społeczeństwo. Gospodarka. Kultura. Polityka, Warszawa 2006; M.M. Drozdowski, Józef Pitsudski. Naczelnik Państwa Polskiego 14 XI 1918 - 14 XII 1922, Warszawa 2008; G. Nowik, Odrodzenie Rzeczypospolitej w myśli politycznej Józefa Pitsudskiego 1918-1922, cz. 1: Sprawy wewnętrzne, Warszawa 2017.
} 
Powyższa problematyka zostanie omówiona w trzech częściach o układzie chronologiczno-problemowym: w okresie powojennego chaosu społeczno-gospodarczego i euforii po odzyskaniu niepodległości w czasie rządów Naczelnika Państwa, realizującego podstawowe reformy jako zapory przeciwko radykalizmowi lewicowemu i prawicowemu (11 XI 1918 - 26 I 1919); w okresie współrządów Sejmu Ustawodawczego i Naczelnika Państwa o kompetencjach ograniczonych na gruncie Małej Konstytucji oraz chwilowej konsolidacji „stygnącego społeczeństwa" w czasie wojny polsko-bolszewickiej (26 I 1919 - październik 1920); w okresie wyrastania z euforii niepodległościowej i konfliktów prowadzących do odmowy Piłsudskiego kandydowania na urząd prezydenta, zabójstwa prezydenta Gabriela Narutowicza i złożenia urzędu Naczelnika Państwa (listopad 1920 - grudzień 1922).

\section{„Polska tworzy się w chaosie”5 (11 XI 1918 - 26 I 1919)}

Odzyskanie niepodległości w listopadzie 1918 r. było procesem złożonym, w którym wzięli udział przedstawiciele licznych organizacji wojskowych, stronnictw politycznych, stowarzyszeń, a także zwykli obywatele. Nie do przecenienia okazała się rola Piłsudskiego, niekwestionowanego przywódcy obozu niepodległościowego, aresztowanego 21/22 VII 1917 r. przez władze niemieckie. Dorobek Piłsudskiego podczas wojny był tak wielki, nawet dla jego przeciwników politycznych, że jesienia $1918 \mathrm{r}$. właśnie w nim widziano męża opatrznościowego, który sprosta trudom odbudowy państwa polskiego. W rezultacie Rada Regencyjna przekazała mu bezzwłocznie po powrocie z Magdeburga najpierw 11 listopada władzę wojskowa, a później 14 listopada władze polityczna jako Naczelnikowi Państwa o dyktatorskich uprawnieniach ${ }^{6}$. Zadania, przed jakimi staną Piłsudski, były ogromne, bo Polska znajdowała się w chaotycznych stosunkach wewnętrznych i zewnętrznych. Do najważniejszych wyzwań należały obrona granic, likwidacja okupacji niemiecko-austriackiej i połączenie w jeden organizm trzech zaborów.

Bardzo groźnie wyglądała sytuacja społeczna pogłębiona przez następstwa wojny: wysiedlenia, migracje w wyniku przymusowej pracy, służby wojskowej i niewoli. Piłsudski zakładał początkowo, że wraz z formalnym odrodzeniem ojczyzny musi iść odrodzenie duszy Polaka ${ }^{7}$. Po powrocie do kraju społeczeństwo stanęło za nim po przekazaniu mu władzy ${ }^{8}$. Moment ten trwał jednak

${ }^{5}$ J. Piłsudski, op. cit., t. V, s. 32.

${ }_{6}^{6}$ J. Pajewski, Odbudowa państwa polskiego 1914-1918, Warszawa 1978, s. 293-301; G. Nowik, op. cit., s. 108-121.

7 J. Piłsudski, op. cit., t. VI, Warszawa 1937, s. 57, Wspomnienie o Gabrielu Narutowiczu, lipiec 1923 r.; ibidem, t. VIII, Warszawa 1937, s. 249-250, Przemówienie do oficerów, składających Piłsudskiemu hołd w siódmą rocznicę jego powrotu z Magdeburga, 15 XI $1925 \mathrm{r}$.

8 „Dumny jestem z tego faktu, dumny jestem nie tylko dlatego, że mnie ten zaszczyt spotkał, ale dumny byłem również ze swego narodu". Ibidem, t. VI, s. 28. 
krótko, bo już pod koniec listopada 1918 r. pod wpływem propagandy obozu narodowego zaczęła upowszechniać się negatywna ocena działań Naczelnika Państwa9. Piłsudski trzeźwo oceniał społeczeństwo, którego stan „upojenia wolnością" musiał kiedyś minąć. Nie miał złudzeń co do jego mizernej moralnej i politycznej kondycji: „Masa społeczeństwa polskiego jest rzeczą niczyja, luźnie chodząca, nie ujętą w żadne kadry organizacyjne. Nie posiadająca żadnych właściwie przekonań, jest masa bez kości i fizjognomii” ${ }^{10}$. Zdaniem Piłsudskiego Polacy byli tak „przesiąknięci chaosem, że naturalny rozwój musiał prowadzić nie do praworządności, o czym w Magdeburgu marzyłem, lecz do silnych tarć wewnętrznych i do panowania samowoli grupowej czy partyjnej"1. Aby usunąc ten stan patologiczny, Piłsudski od samego początku postawił sobie zadanie zwołania sejmu i przerwanie bawienia się „każdej partyjki w cały naród, w którego imieniu te grupy usiłowały ciagle przemawiać" ${ }^{12}$.

Odrzucił sugestię, podpowiadana przez niektórych współpracowników, dłuższego trzymania w karbach społeczeństwa niż zapowiadane wybory, „które w nastroju, jaki panuje, nie wiadomo, co dać moga"13. Dla Piłsudskiego przedłużenie stanu dyktatorskiego było sprzeczne z jego przekonaniami i poczuciem wolności, ale przede wszystkim stwarzało sytuację nielegalna, bez prawa, co mogłoby zaszkodzić Polsce w opinii świata. Wierzył, że społeczeństwo się uspokoi, a zagranica zobaczy, że nikt nie chce w Polsce bolszewizmu ${ }^{14}$.

9 Janina Gajewska, zwolenniczka ugrupowań narodowych, zapisała 29 XI 1918 r.: „Piłsudski jest dziwny człowiek. Jego stanowisko zajęte względem Lwowa, mianowanie wybitnie socjalistycznego gabinetu, i zbyt miękkie na ogół postępowanie z Niemcami, zniechęciło do niego od razu wielkie masy narodu, i ci którzy stawiali mu ołtarze, dziś jak to zwykle u nas, psy na nim wieszaja. A przecież był najpopularniejszym w kraju człowiekiem i nazwisko jego noszono na czapkach i konie mu wyprzęgano z powozu. Nigdy się do niego nie entuzjazmowałam, ale w ostatnich chwilach, gdy wrócił z niewoli, wierzyłam zamknąwszy oczy na jego socjalizm - że ten półbożek, którego zaczynano już porównywać z Kościuszka, ujmie naprawdę silną dłonią ster naszego chaosu, a przede wszystkim, że okaże się naprawdę wielkim człowiekiem i wzniesie się ponad interesy swojej partii. Tymczasem - partia, partyjny, partyjność, oto hasło dnia dzisiejszego". Ta wojna zmieni wszystko... Dzienniki Janiny Gajewskiej, oprac. A. Wajs, Warszawa 2014, s. 305. Zob. U. Jakubowska, Publicystyka Narodowej Demokracji wobec Józefa Pitsudskiego w okresie międzywojennym, w: Pitsudski na tamach $i$ w opiniach prasy polskiej 1918-1989, red. M. Jabłonowski, E. Kossewska, Warszawa 2005, s. 97-118; G. Nowik, op. cit., s. 117-118.

${ }^{10}$ Listy Józefa Piłsudskiego, wstęp K. Świtalski, „Niepodległość” 1962, t. VII, s. 12, List do Romana Dmowskiego Przewodniczącego Komitetu Narodowego w Paryżu (22-26 I 1919).

11 J. Piłsudski, op. cit., t. V, s. 182.

${ }^{12}$ Ibidem. Piłsudski odrzucał alternatywy dla demokracji, jakie prezentował ruch rewolucyjny $\mathrm{w}$ postaci powoływanych rad, jak i ruch narodowy propagujacy zwołanie na czas nieokreślony Zgromadzenia Narodowego lub Naczelnej Rady Narodu Polskiego. G. Nowik, op. cit., s. 277-285.

${ }^{13}$ W. Baranowski, Rozmowy z Pitsudskim 1916-1931, Warszawa 1990, s. 51. Krzysztof W. Mucha przypisuje błędnie te słowa Piłsudskiemu. K.W. Mucha, Parlament Polski w opinii Józefa Pitsudskiego 1918-1930, „Acta Universitatis Lodziensis. Folia Historica” 2001, t. LXXI, s. 28.

${ }^{14}$ W. Baranowski, op. cit., s. 52. 
Rozchwianie społeczeństwa i jego radykalizację bez skrupułów wykorzystywali agenci bolszewiccy, powołując rady, wydając odezwy i prowadząc agitację ludności, w tym także żołnierzy ${ }^{15}$. Nakazem chwili było uśmierzenie rewolucyjnych nastrojów. W przypadku Piłsudskiego zrozumienie tego ułatwiały postępowe przekonania wyniesione z politycznej działalności w PPS ${ }^{16}$. Przyją on zasadę, że to lud polski musi odegrać w tym okresie decydująca rolę i „licząc się z potężnymi prądami, zwyciężającymi dzisiaj na zachodzie i wschodzie Europy", postanowił utworzyć rząd na podstawach demokratycznych i z wybitnym udziałem przedstawicieli "ludu wiejskiego i miejskiego" ${ }^{17}$. Potwierdził to w depeszy notyfikującej powstanie państwa polskiego, wysłanej 16 listopada do głów państw demokratycznego Zachodu. Rząd polski miał zastapić panowanie przemocy, wprowadzone przez państwa zaborcze poprzez ustrój zbudowany na porządku i sprawiedliwości ${ }^{18}$.

Piłsudski desygnował na premiera socjalistę Ignacego Daszyńskiego (premiera rządu ludowego powołanego 6 XI 1918 r. w Lublinie ${ }^{19}$ ), zażądał jednak powołania w skład gabinetu niezbędnych fachowców, niezależnie od ich przekonań politycznych, a także powstrzymania się na razie od przeprowadzenia głębokich zmian społecznych. Tłumaczył to prowizoryczną natura rządu do czasu zwołania w krótkim terminie Sejmu Ustawodawczego, który miałby prawo przeprowadzenia niezbędnych reform ${ }^{20}$.

Po załamaniu się misji Daszyńskiego, krytykowanego przez prawicę narodowa, nowym kandydatem na premiera został 18 XI 1918 r. socjalista Jędrzej Moraczewski. Przed powołaniem Piłsudski oświadczył mu, że tak się stanie pod dwoma warunkami: niewkraczania zarządzeniami w stosunki społeczne i opracowania w krótkim czasie ordynacji wyborczej ${ }^{21}$. Motywy ponownego desygnowania przez Naczelnika Państwa na stanowisko premiera socjalisty ujawnia jego instrukcja (wydana po 27 XI 1918 r.) w związku z przygotowaniami do wysłania delegacji do Paryża. Największe zagrożenia dla niepodległości Polski i jej stosunków wewnętrznych widział Piłsudski w bolszewizmie i w wojskach niemieckich obecnych jeszcze na kresach. Nad polityką wewnętrzną ciążyły spuścizna niewoli i długotrwały brak własnego

${ }_{15}$ W. Suleja, Józef Piłsudski, Wrocław 1995, s. 176; O Niepodlegta i granice, [t. II]: Raporty $i$ komunikaty naczelnych wtadz wojskowych o sytuacji wewnętrznej Polski 1919-1920, oprac. M. Jabłonowski, P. Stawecki, T. Wawrzyński, Warszawa-Pułtusk 1999-2000, s. 17, 21-24, 28-29, 34-37; J. Moraczewski, Przewrót w Polsce, Warszawa 2015, s. 81-84, 114-115; G. Nowik, op. cit., s. 277-280.

${ }_{16}$ G. Nowik, op. cit., s. 331-342.

17 J. Piłsudski, op. cit., t. V, s. 18-19, Oświadczenie opublikowane przez prase 14 XI 1918.

18 Ibidem, t. V, s. 20.

19 S. Thugutt, Autobiografia, Warszawa 1984, s. 109-114.

${ }^{20}$ J. Piłsudski, op. cit., t. V, s. 18-19; A. Próchnik, Pierwsze piętnastolecie Polski niepodlegtej (1918-1933), Warszawa 1983, s. 31-33; M.M. Drozdowski, Józef Piłsudski..., s. 15, 43.

21 J. Piłsudski, op. cit., t. V, s. 205; S. Thugutt, op. cit., s. 114-124; Gabinety Drugiej Rzeczypospolitej, red. J. Faryś, J. Pajewski, Poznań 1991, s. 29-39. 
państwa. Zdaniem Piłsudskiego Polska była utrzymywana przez zaborców w warunkach nienormalnych i celowo cofana w rozwoju społecznym. W rezultacie te nieznane w Europie stosunki należało przełamywać wyjątkowymi środkami, aby uratować naród od grożącego mu rozluźnienia więzi społecznych i zapanowania bolszewizmu. Naczelnik Państwa ustanowił rząd lewicowy, bo chciał, aby ustawa wyborcza została zrobiona przez lewicę, by „wśród szerokich warstw ludowych nie powstało ani na chwile podejrzenie, jakoby się chciało w tej sprawie oszukiwać lud”. Ponadto Piłsudski chciał włączyć w proces stworzenia rządu tę część lewicy, która dawała gwarancję utrzymania ładu i porządku w kraju. Według Piłsudskiego lewicowy rząd był niczym „wstrzyknięcie choroby z wywołaniem nawet pozornego i chwilowego zaburzenia organizmu" w celu uchronienia go od choroby gorszej ${ }^{22}$.

Naczelnik Państwa powstrzymał się z głębokimi przeobrażeniami społecznymi, np. upaństwowieniem wielkiej własności ziemskiej czy pewnych działów produkcji, do czasu zwołania Sejmu Ustawodawczego. Czując jednak oczekiwanie ludzi na zmiany, wprowadził wraz z premierem Moraczewskim od listopada 1918 do lutego 1919 r. pakiet reform socjalnych. 23 listopada podpisał dekret o ośmiogodzinnym dniu pracy i czterdziestogodzinnym tygodniu pracy, później doszedł dekret o moratorium mieszkaniowym dla osób bez pracy oraz dekret o ochronie lokatorów ${ }^{23}$. Powołano też inspekcję pracy, zalegalizowano zwiazki zawodowe, wprowadzono ubezpieczenia na wypadek choroby, wprowadzono obowiązek szkolny, uregulowano sprawę ochrony i użytkowania lasów ${ }^{24}$.

Pakiet zmian społecznych uzupełniały ważne reformy polityczne, m.in. dekret z 22 listopada regulował organizację Republiki Polskiej. Władzę miał sprawować Piłsudski jako tymczasowy Naczelnik Państwa, który mianuje rząd przed nim odpowiedzialny. Władzę ustawodawczą, należącą do rządu, wykonywano za pomoca dekretów zatwierdzanych przez Piłsudskiego, podobnie jak budżet. Sądy wydawały wyroki w imieniu Republiki Polskiej ${ }^{25}$. Szczególne znaczenie miało przyznanie praw wyborczych wszystkim obywatelom, którzy ukończyli 21 lat, w tym także kobietom ${ }^{26}$, stanowiące znak, że Polska zaczyna

${ }^{22}$ Polskie dokumenty dyplomatyczne. 1918 listopad-grudzień, red. S. Dębski, współpr. P. Długołęcki, Warszawa 2008 (dalej: PDD 1918), s. 108-110. Argumentację tę powtórzył Piłsudski w liście z 11 XII 1918 r. do narodowego demokraty Stanisława Grabskiego, podkreślając, że powołał rząd lewicowy w celu ratowania kraju przed rewolucją bolszewicka. M.M. Drozdowski, Józef Piłsudski..., s. 25; W. Suleja, Józef Piłsudski..., s. 185.

${ }^{23}$ S. Kutrzeba, Polska odrodzona, Kraków 1988, s. 86-87; M.M. Drozdowski, Józef Pitsudski..., s. 22; J. Pajewski, Budowa Drugiej Rzeczypospolitej..., s. 41-42; J. Moraczewski, op. cit., s. 99-101.

${ }^{24}$ M.M. Drozdowski, Józef Pitsudski..., s. 50-52; A. Próchnik, op. cit., s. 35-36; J. Moraczewski, op. cit., s. 121-122; G. Nowik, op. cit., s. 351-357.

${ }^{25}$ A. Próchnik, op. cit., s. 34-35.

${ }^{26}$ Powstanie II Rzeczypospolitej. Wybór dokumentów 1866-1925, red. H. Janowska, T. Jędruszczak, Warszawa 1981, s. 448-451, Dekret Naczelnika Państwa o ordynacji wyborczej do 
dotrzymywać kroku postępowym zmianom w Europie ${ }^{27}$. Towarzyszyły temu reformy samorządowe regulowane dekretami o stworzeniu rad gminnych (27 listopada), o tymczasowej ordynacji wyborczej do sejmików powiatowych (5 grudnia) oraz o wyborach do rad miejskich na ziemiach byłego Królestwa Kongresowego (13 grudnia) ${ }^{28}$. Grzegorz Nowik ocenił te reformy jako przewrót społeczny, w majestacie prawa zgodny z programem paryskim PPS z $1892 \mathrm{r}$. i uwzględniony w deklaracji premiera Moraczewskiego z 21 XI 1918 r. ${ }^{29}$ W rzeczywistości te rewolucyjne zmiany były próbą dostosowania stosunków w Polsce do standardów państw Zachodu.

Stawiając diagnozę, że Polska tworzy się w chaosie, Piłsudski widział potrzebę znalezienia stabilnego punktu odniesienia. Jednym z przykładów szybkiego ustanowienia porządku wewnętrznego i organizowania się miało być wojsko polskie. W rozkazie o jednolitości armii, wydanym 7 XII 1918 r., apelował do dowódców o wprowadzenie w oddziałach ,jednolitego ducha” i usunięcie wszelkich przejawów odrębnego patriotyzmu ${ }^{30}$. Innym filarem ładu w państwie powinien być szybko zwołany parlament. We wspomnianej instrukcji z końca 1918 r. argumentował, że państwo polskie buduje się zupełnie na nowo i nie ma żadnej tradycji i prawnego oparcia. Natomiast konstytuanta dawała „krajowi pierwsze poczucie prawa dokonanego bez udziału obcych" i stanowiła tamę przeciw bolszewizmowi ${ }^{31}$. Nie obawiał się zradykalizowania konstytuanty i przez konstytuantę kraju, gdyż w Polsce będzie ją wybierać ogromna konserwatywna większość chłopska. Konstytuanta miała być formą złączenia dzielnic w jedna całość i wyrównania różnic ${ }^{32}$. Deklarował podporządkowanie się wybranym przez naród reprezentantom. Uzasadnienie tego kroku przedstawił 27 I 1919 r. w wywiadzie dla dziennika „Le Petit Journal” tuż przed ogłoszeniem wyników wyborów do Sejmu Ustawodawczego: „Moje przekonania polityczne sa znane, ale na stanowisku, na którym się znajduję, nie zajmuję się polityką wewnętrzna. Do mnie należy zapewnienie porządku, dowodzenie wojskami i poddanie się woli, swobodnie wyrażonej przez naród"33.

Istotny wpływ na sytuację w odrodzonej Rzeczypospolitej miała fatalna kondycja gospodarki. Zadecydowały o tym długoletnie zaniedbania spowodowane

Sejmu Ustawodawczego, Warszawa, 28 XI 1918; S. Kutrzeba, op. cit., s. 86-88; G. Nowik, op. cit., s. 348-349.

${ }^{27}$ Po zakończeniu wojny prawa wyborcze otrzymały m.in. 12 XI 1918 kobiety w Austrii.

B. Bader-Zaar, Wahlrecht, w: Österreich..., s. 25-34.

28 J. Moraczewski, op. cit., s. 85-88, 121-123.

${ }^{29}$ Ibidem, s. 88-90, 161-167; G. Nowik, op. cit., s. 347-357.

30 J. Piłsudski, op. cit., t. V, s. 33-34. Piłsudski przestrzegał również przed wciaganiem wojska do politycznych rozgrywek. Ibidem, t. V, s. 29; W. Suleja, op. cit., s. 184.

${ }^{31}$ PDD 1918, s. 110.

${ }^{32}$ Ibidem, s. 110.

${ }^{33}$ J. Piłsudski, op. cit., t. V, s. 55. 
rządami państw zaborczych. Polska odziedziczyła ziemie peryferyjne, z reguły słabo rozwinięte gospodarczo, z przewagą rolnictwa i nielicznymi ośrodkami przemysłowymi ${ }^{34}$. Do tego doszły zniszczenia wojenne, taktyka spalonej ziemi zastosowana przez Rosjan podczas odwrotu w 1915 r., rabunkowa gospodarka niemiecka, szczególnie na obszarach leśnych. Według szacunków Komisji Odszkodowań delegacji polskiej na konferencji pokojowej w Paryżu straty przemysłu polskiego poniesione podczas wojny wyniosły 10 mld franków w złocie, odłogiem leżało $45 \mathrm{mln}$ ha ziemi uprawnej, ubyło $30-30 \%$ inwentarza żywego, zniszczonych zostało 1,8 mln budynków mieszkalnych i gospodarczych, a na wsi ponad pół miliona gospodarstw rolnych ${ }^{35}$. W notatce prezydenta Warszawy z 19 XII 1918 r. dla Komitetu Narodowego Polskiego (KNP) szkody miasta Warszawy, powstałe w wyniku okupacji niemieckiej, wyceniono na 267 mln marek. Podkreślono też, że po zakończeniu okupacji stan nie uległ poprawie ${ }^{36}$. Piłsudski po powrocie 10 XI 1918 r. z Magdeburga do Warszawy znalazł Polskę „obrabowaną i zniszczona, stojąca od pierwszej chwili swojego istnienia w ogniu walki orężnej bez kawałka broni, zmuszona natychmiast błagać u obcych o pomoc dla wyżywienia swoich obywateli" ${ }^{37}$.

Racja stanu wymagała uruchomienia przemysłu, ale na drodze do realizacji tego celu piętrzyły się trudności, m.in. działania agitatorów. Zdaniem ministra przemysłu i handlu Jerzego Iwanowskiego z 4 XII 1918 r. „robota ta znajduje dla siebie grunt przygotowany przez polityczna niewolę i kultywowaną przez nią ciemnotę i jako pewnik stwierdzić trzeba, że nastroje bolszewickie wśród mas ludowych szerzą się w tempie zatrważającym" ${ }^{38}$. Delegaci Towarzystwa Przemysłowców skarżyli się 11 XII 1918 r. Piłsudskiemu na anarchię panująca w fabrykach i domagali się podjęcia działań, zwłaszcza poprawienia aprowizacji ${ }^{39}$.

Groźne były też informacje o sytuacji na wsi. Przedstawiciele ziemian alarmowali w grudniu 1918 r. o strajkach rolnych, wyrębie lasów rządowych

${ }^{34}$ W. Morawski, Od marki do złotego. Historia finansów Drugiej Rzeczypospolitej, Warszawa 2008, s. 9-43; idem, Dzieje gospodarcze Polski, wyd. 2, Warszawa 2011, s. 135-176.

${ }^{35}$ A. Ajnenkiel, op. cit., s. 39; A. Wierzbicki, Żywy Lewiatan. Wspomnienia, wstęp i oprac. P. Wierzbicki, Warszawa 2001, s. 177-196; M. Leczyk, op. cit., s. 128-129; G. Nowik, op. cit., s. 381.

${ }^{36}$ PDD 1918, s. 302-304.

37 J. Piłsudski, op. cit., t. V, s. 179, 276-277; J. Moraczewski, op. cit., s. 73-75. Podobne były wrażenia Andrzeja Wierzbickiego w kwietniu 1919 r.: „Co do nadzwyczajnych niewygód, jakie musi znosić, brak zaspokojenia najprymitywniejszych potrzeb, które porównać można tylko - i to nie będzie nic powiększone, przeciwnie raczej - $\mathrm{z}$ odwrotem armii Napoleona z Rosji. Są ludzie bosi, odziani absolutnie w strzępach, absolutnie głodni... I ci bohaterowie bronią Lwowa, idą na kresy wschodnie, do Galicji zachodniej...” Polskie dokumenty dyplomatyczne. 1919 styczeń-maj, red. S. Dębski, Warszawa 2016 (dalej: PDD 1919), s. 594, Sprawozdanie z posiedzenia Delegacji Ekonomicznej odbytego w Paryżu, dnia 3 IV 1919 r.

38 PDD 1918, s. 171.

${ }^{39}$ J. Piłsudski, op. cit., t. V, s. 36. 
i prywatnych oraz o anarchii na wsi, podsycanej przez lewicowe partie polityczne $^{40}$. Na postulaty delegatów Socjalnej Demokracji Królestwa Polskiego i Litwy, którzy przedstawili ciężkie położenie materialne bezrobotnych i domagali się od rządu mieszkań, chleba, pracy i opieki, Piłsudski oświadczył, że sprawa robót publicznych stanowi jedno z najważniejszych zagadnień państwowych, przyrzekł poprzeć żądania bezrobotnych i obiecał porozumieć się $\mathrm{w}$ tej sprawie z premierem Moraczewskim. Odpowiadajac na demagogiczne przemówienie delegata górników, zalecił zachowanie spokoju i cierpliwości, gdyż „uregulowanie stosunków ekonomicznych w Polsce musi iść równomiernie z działalnością w tej mierze całej Europy zachodniej" ${ }^{41}$.

Piłsudski wyciagną wnioski z konsultacji społecznych. W instrukcji z 19 XII 1918 r. dla delegacji nadzwyczajnej Tymczasowego Naczelnika Państwa do państw Ententy i KNP podkreślono znaczenie spraw aprowizacyjnych. Szybkie ich załatwienie uznano ,jako jedyne zbawienie od rozkładu społecznego wewnątrz, sama wiadomość o tej pomocy wpłynie na ujawnienie zapasów ukrytych" ${ }^{2}$. Nie mniej ważna była pożyczka w wysokości 2 mld franków w celu „zaprowadzenia frankowej waluty w Polsce”, rozwinięcia handlu zewnętrznego oraz usunięcia zdeprecjonowanych walut obcych z kraju ${ }^{43}$. W styczniu 1919 r. dotarła do Polski ze Stanów Zjednoczonych żywność warta ok. miliona dolarów, a kolejne miesiące przyniosły poprawę sytuacji dzięki Amerykańskiej Administracji Pomocy Herberta Hoovera (ARA) ${ }^{44}$. 16 I 1919 r. powstało Ministerstwo Robót Publicznych. 8 lutego Naczelnik Państwa przeznaczył 75 mln marek polskich na ożywienie przemysłu polskiego ${ }^{45}$. Powyższe działania miały charakter doraźny. Odbudowanie komunikacji, miast, przemysłu, a przede wszystkim połączenie w jeden organizm gospodarczy różnych dzielnic wymagało znacznych środków finansowych i technicznych ${ }^{46}$. Państwo polskie nie dysponowało takimi środkami. Mogło je uzyskać tylko od zwycięskiej koalicji. Klucz do nawiązania z nią kontaktów znajdował się w rękach KNP w Paryżu, na którego czele stał prezes Roman Dmowski, dobrze notowany przez państwa Zachodu. Konieczne były osiagnięcie porozumienia z prawica narodową i zmiana rządu socjalistycznego na ogólnonarodowy, co Piłsudski zakładał w listopadzie 1918 r. ${ }^{47}$

O wpływie trudnej sytuacji gospodarczej w Polsce na decyzję o powołaniu 16 I 1919 r. rządu Ignacego Paderewskiego, światowej sławy pianisty,

\footnotetext{
${ }^{40}$ M.M. Drozdowski, Józef Pitsudski..., s. 24; O Niepodlegta i granice..., passim.

${ }^{41}$ J. Piłsudski, op. cit., t. V, s. 38.

${ }^{42}$ PDD 1918, s. 300.

${ }^{43}$ Ibidem.

${ }^{44}$ M.M. Drozdowski, Ignacy Jan Paderewski. Zarys biografii politycznej, Warszawa 1979, s. 142 ; G. Nowik, op. cit., s. 385.

${ }^{45}$ G. Nowik, op. cit., s. 383.

${ }^{46}$ PDD 1918, s. 113, Instrukcja Tymczasowego Naczelnika Państwa w związku z przygotowaniami do wysłania delegacji do państw Ententy, po 27 XI 1918; G. Nowik, op. cit., s. 382.

47 PDD 1918, s. 110.
} 
świadczy list z 17 stycznia Naczelnika Państwa do przewodniczącego delegacji warszawskiej w Paryżu, Kazimierza Dłuskiego: „Brak środków technicznych i brak możności wytworzenia ich w Polsce zmuszał w polityce zewnętrznej skierować wszystkie wysiłki w kierunku uzyskania od Ententy pomocy pieniężnej, aprowizacyjnej i uzyskania od niej broni" ${ }^{48}$. Ponadto nie dopilnowano emisji nowych banknotów, a mieszkańcy Wielkopolski, „którzy maja w zanadrzu miliony, nie chcieli pieniędzy tych oddać do dyspozycji gabinetu Moraczewskiego". Celem rządu Paderewskiego, utrzymującego dobre stosunki z Dmowskim i Francuzami, było uzyskanie pomocy od Ententy i wybrnięcie z zapaści finansowej ${ }^{49}$. Inny motyw do zmiany rządu stanowiły potrzeby wojskowe - rozbudowa armii i jej zaopatrzenie ${ }^{50}$.

Kompromis forsowany przez Piłsudskiego wynikał także z chęci pacyfikacji rosnaccych aspiracji KNP do przejęcia władzy w kraju. Przejawem tego były nie tylko zabiegi dyplomatyczne KNP wśród zachodnich rządów czy masowe demonstracje $\mathrm{w}$ Polsce organizowane przez narodowych demokratów. Na posiedzeniach KNP, w obecności prezesa Dmowskiego, dyskutowano o możliwości politycznego zamachu stanu w kraju i interwencji armii Józefa Hallera $^{51}$. W kontekście starań o usunięcie rządu Moraczewskiego widzieć należy nieudany zamach płk. Mariana Januszajtisa i ks. Eustachego Sapiehy z 4 na 5 I 1919 r. ${ }^{52}$ Starania KNP i prezesa Dmowskiego nie przyniosły rezultatów i zwycięzca konfrontacji został Piłsudski. Zdaniem Janusza Pajewskiego „wzmocnił swoje naczelne w państwie stanowisko, nikt odtąd stanowiska tego nie mógł kwestionować”. Paderewski podporządkował mu się, gdy przyjął z jego rąk nominację, zarazem ułatwił uznanie Naczelnika Państwa przez Ententę. KNP, do niedawna pretendujący do odegrania roli rządu, stał się praktycznie tylko przedstawicielstwem zagranicznym władz polskich w kraju ${ }^{53}$.

Rząd Paderewskiego przystapił bezzwłocznie do pracy. Minister skarbu Józef Englich wysłał 24 I 1919 r. list do KNP w sprawie konieczności zaciagnięcia pożyczki zagranicznej. Do wykonania olbrzymich zadań, stojących przed

${ }_{48}$ PDD 1919, s. 89.

${ }^{49}$ Ibidem, s. 90; Gabinety Drugiej Rzeczypospolitej..., s. 41-53; M.M. Drozdowski, Józef Pitsudski..., s. 34-35.

${ }^{50}$ M.M. Drozdowski, Ignacy Jan Paderewski..., s. 141-145; W. Baranowski, op. cit., s. 57-58; W. Suleja, op. cit., s. 190-192.

${ }^{51}$ PDD 1918, s. 220-221, Protokół konferencji KNP z delegatami z kraju odbytej dnia 11 XII 1918 r.

${ }^{52}$ S. Thugutt, op. cit., s. 124-129; A. Garlicki, Jerzy Zdziechowski o styczniowym zamachu stanu 1919 r., „Przegląd Historyczny” 1977, t. LXVIII, z. 1, s. 143-146; J. Pajewski, Odbudowa państwa polskiego..., s. 321-329; A. Próchnik, op. cit., s. 38-39; W. Suleja, op. cit., s. 191-192.

${ }^{53}$ J. Pajewski, Odbudowa państwa polskiego..., s. 328-329; K. Lundgreen-Nielsen, Wielkie mocarstwa a Polska 1918-1919, „Niepodległość” 1981, t. XIV, s. 27-43; W. Suleja, op. cit., s. $190-193$. 
państwem polskim, niezbędne były środki, których nie miał kraj wyczerpany wojną. Pomimo zapału, występującego w najszerszych warstwach narodu, pożyczka wewnętrzna dawała sumy niewystarczające. Jedyne wyjście widział w zaciagnięciu wielkiej pożyczki zagranicznej ${ }^{54}$. Z inicjatywy Komitetu zorganizowano i wysłano do Paryża na konferencję pokojową delegację ekonomiczna. Na jej czele stanął narodowy demokrata, przemysłowiec Andrzej Wierzbicki, który 9 lutego został powołany na członka KNP, a rząd Paderewskiego mianował go na przewodniczącego Delegacji Ekonomicznej przy delegacji pokojowej dla spraw traktatowych oraz do koordynowania działań w celu odnowienia polskich stosunków gospodarczych na terenie Francji i Anglii ${ }^{55}$. Rząd Paderewskiego, m.in. pod wpływem doradców amerykańskich, wziął kurs na rozszerzenie gospodarki towarowej i coraz mniejszą reglamentację. Odrzucono ideę nacjonalizacji przemysłu, z wyjątkiem zakładów stanowiących własność państw centralnych. Kapitał prywatny zaczął stopniowo uczestniczyć w odbudowie przemysłu ${ }^{56}$.

Atmosferę społeczna podgrzewały zbliżające się wybory parlamentarne. Naczelnik Państwa krytycznie oceniał kampanię prowadzoną przez ugrupowania polityczne. Piłsudski wiedział, co mówi, gdyż przez pierwsze tygodnie po jego powrocie większość rozmówców, z którymi się spotykał, była opanowana „megalomanią wyjątkowa”: „Twierdzenie: ja, lub my i naród, to jedno - nie schodziło z ust, każdy to powtarzał, każdy rwał się do reprezentowania na swoją rękę Polski wewnątrz i zewnątrz”57. W prowadzonym „duszołapstwie” chodziło o przyciąnięcie choćby na jeden moment bezmyślnej „gawiedzi”. Nie było to trudne, gdyż społeczeństwo znajdowało się na poziomie ,politycznego niemowlęctwa”. Normę stanowiły „spekulacja na najbardziej prymitywne i naiwne odruchy mas”, „zapominanie o interesach całości państwa”, a „deklaracja o Ojczyźnie frazesem, z którym działalność deklamujacych stoi w najzupełniejszej sprzeczności"58. Te krytyczne uwagi Piłsudskiego były w pierwszym rzędzie wymierzone w Narodową Demokrację.

Według Piłsudskiego lewica dostała wszystko, czego zapragnąc mogła, i tylko od niej zależało wprowadzenie do sejmu swojej większości dla zachowania dorobku rządu Moraczewskiego ${ }^{59}$. Piłsudski nie krył, że jako sługa narodu złoży władzę konstytuancie, bez względu na jej skład. 1 II 1919 r. oświadczył włoskiemu dziennikarzowi: „Gdyby Sejm konstytucyjny chciał ustalić ustrój konserwatywny, jako żołnierz spełnię mój obowiązek i oddam mu się do rozporządzenia, by służyć memu krajowi. Uważam ten Sejm jako

\footnotetext{
${ }^{54}$ PDD 1919, s. 138.

${ }_{55}$ A. Wierzbicki, op. cit., s. 20-26.

${ }^{56}$ M.M. Drozdowski, Józef Piłsudski..., s. 173-174.

${ }^{57}$ J. Piłsudski, op. cit., t. V, s. 182.

${ }^{58}$ Listy Józefa Piłsudskiego..., s. 12, List do Romana Dmowskiego Przewodniczącego Komitetu Narodowego w Paryżu (22-26 I 1919).

${ }^{59}$ W. Baranowski, op. cit., s. 52.
} 
wyraz woli Narodu i w każdym wypadku oddam Ojczyźnie cała moją pracę żołnierska”. Ocenił sytuację społeczna jako spokojna, pomimo trudności ekonomicznych, w jakich znaleźli się robotnicy, ogromnego bezrobocia, drożyzny i trudności aprowizacyjnych. To patriotyzm pozwalał „znosić z rezygnacją te ciężkie chwile życia”, dlatego bolszewizm nie przedstawiał niebezpieczeństwa i nie miał wpływu na ludnośćco.

\section{Stygnące społeczeństwo (26 I 1919 - wrzesień 1920)}

Stan tymczasowy państwa zakończyły sprawnie przeprowadzone 26 I 1919 r. wybory do Sejmu Ustawodawczego. Większość społeczeństwa, zwłaszcza z zaboru rosyjskiego, brała w nich udział po raz pierwszy, frekwencja była wysoka i osiagnęła ponad 70\% (rekordowe $94,4 \%$ w okręgu Konin) ${ }^{61}$. Piłsudski widział w tym efekt „Polski zmartwychwstałej”. W wywiadzie dla dziennika „Le Matin” 19 lutego oświadczył: „Jeżeli bezrobotny o pustym żołądku i bosy poszedł radośnie głosować, znaczy to, że w nim jedna myśl góruje ponad innymi: Polska zmartwychwstała. Okrzyk ten jest teraz silniejszy od głodu i chłodu; wypełnia on obecnie serca wszystkich Polaków; może on doprowadzić ich do wszelkich poświęceń" ${ }^{2}$.

Wybory wygrała jednak nie lewica $(26,8 \%)$, lecz prawica narodowa $(35,8 \%)$, z której szeregów wywodzili się najwięksi przeciwnicy Piłsudskiego. Najwyraźniej bezwzględne metody walki politycznej, odwołujące się do naiwnych i prymitywnych odruchów mas, okazały się skuteczne. Piłsudski zgodnie z obietnica 20 II 1919 r. na trzecim posiedzeniu sejmu złożył urząd Tymczasowego Naczelnika Państwa. Jednocześnie oświadczył: „Wśród olbrzymiej zawieruchy, w której miliony ludzi rozstrzyga sprawy jedynie gwałtem i przemoca, dążyłem, by właśnie w naszej Ojczyźnie konieczne i nieuniknione tarcia społeczne były rozstrzygane w sposób jedynie demokratyczny: za pomoca praw, stanowionych przez wybrańców narodu" ${ }^{63}$. Nowy sejm, mimo przewagi partii prawicowo-centrowych nad ugrupowaniami lewicowymi, nie uszczuplił praw obywatelskich ustanowionych dekretami przez Naczelnika Państwa, lecz je rozszerzył, m.in. regulując zatargi zbiorowe ${ }^{64}$. Dokładnie na odwrót postapił z kompetencjami Naczelnika Państwa, ograniczając je na mocy Małej Konstytucji, uchwalonej 20 II 1919 r., do reprezentacji państwa i spraw wojskowych ${ }^{65}$.

${ }^{60}$ Ibidem, s. 60-61.

${ }^{61}$ Cz. Brzoza, A.L. Sowa, Historia Polski 1918-1945, Kraków 2006, s. 258; J. Pajewski, Budowa Drugiej Rzeczypospolitej..., s. 46-48.

${ }^{62}$ J. Piłsudski, op. cit., t. V, s. 58-59; M.M. Drozdowski, Józef Piłsudski..., s. 40.

${ }^{63}$ J. Piłsudski, op. cit., t. V, s. 60.

${ }^{64}$ W. Pobóg-Malinowski, Najnowsza historia polityczna Polski 1864-1945, Londyn 1956, s. 15; A. Próchnik, op. cit., s. 66; G. Nowik, op. cit., s. 360.

65 S. Kutrzeba, op. cit., s. 119-120; A. Próchnik, op. cit., s. 54-55; W. Suleja, op. cit., s. 195-196; G. Nowik, op. cit., s. 298-310. 
W pierwszym okresie niepodległości, co przyznał Piłsudski, należało zając się walką z obcym panowaniem. Nie było czasu na pracę nad postępem socjalnym i nad dobrobytem ludu, mimo że występowały obiektywne przesłanki sprzyjajace niezadowoleniu i radykalizacji społeczeństwa: nędza, brak pracy i przymusowe bezrobocie. „Upojenie wolnościa” wpływało łagodząco na sytuację społeczna ${ }^{66}$. Zapał narodu i zrozumienie dla racji stanu dostrzegł też Andrzej Wierzbicki w kwietniu 1919 r. Były jednak niezbędne minima pomocy materialnej, czyli „buty i sukna dla żołnierza polskiego"67.

Po wyborach parlamentarnych premier Paderewski podążał droga zgody narodowej i społecznej. W swoim exposé wygłoszonym w sejmie 20 lutego zadeklarował wolę potwierdzenia wprowadzonych reform społecznych i praw socjalnych oraz polepszenie losu robotników. W związku z głodem ziemi na wsi obiecał małorolnym i bezrolnym pracę, chleb i ziemię ${ }^{68}$. Powyższych obietnic nie było łatwo zrealizować z powodu trudnej sytuacji gospodarczej. W $1919 \mathrm{r}$. wydobycie i produkcja podstawowych artykułów przemysłowych w stosunku do roku 1913 r. wynosiły: węgla kamiennego $-66,0 \%$, ropy naftowej $-77,6 \%$, rudy żelaza $-28,9 \%$, stali $-2,9 \%$, wyrobów walcowanych $-21,7 \%$, cementu $29,9 \%$. Dochód narodowy osiagał zaledwie 30\% przedwojennego, a na jednego mieszkańca - 34\% ${ }^{69}$. Naczelnik Państwa, świadomy konsekwencji politycznych trudnej sytuacji gospodarczej, remedium widział nie w eksperymentach, lecz w rozwiązaniach wypracowanych przez państwa demokratyczne ${ }^{70}$. Podczas przemówienia na otwarcie Sejmu Ustawodawczego 20 II 1919 r. oświadczył, że należyte uregulowanie spraw znajdującego się w upadku przemysłu i przeprowadzenie reform agrarnych „w duchu postępu i wielkich demokracji Zachodu" stworzą trwałe podłoże dla budowy przyszłości Polski ${ }^{71}$. W opinii tej nie był odosobniony. Socjalista Daszyński na posiedzeniu sejmu 27 III 1919 r. przekonywał, że gospodarczy rozwój kapitalistyczny przyczyni się nie tylko do poprawy gospodarki, ale także podniesie zarobki, które z robotnika zrobia światłego obywatela kraju ${ }^{72}$.

W ocenie z 4 IV 1919 r. Andrzeja Wierzbickiego, prezesa Delegacji Ekonomicznej w Paryżu, przyczyny zamarcia życia gospodarczego spowodowane były nie przez administrację państwowa, tylko przez paraliż życia społecznego ${ }^{73}$.

66 J. Piłsudski, op. cit., t. V, s. 58, 276.

${ }^{67}$ PDD 1919, s. 594, Sprawozdanie z posiedzenia Delegacji Ekonomicznej odbytego w Paryżu, dnia 3 I 1919 r.

${ }^{68}$ G. Nowik, op. cit., s. 359-360.

${ }_{69}$ M.M. Drozdowski, Józef Piłsudski..., s. 174; K. Badziak, op. cit., s. 234-243.

${ }^{70}$ Piłsudski traktował jako przestrogę eksperyment społeczny w Rosji, także w wymiarze władzy absolutnej, którą został obdarzony po powrocie z Magdeburga. „Mogłem ją zachować, ale spostrzegłem, że Polska winna być ostrożna, bo jest młodą i biedną. Musi unikać ryzykownych eksperymentów”. J. Piłsudski, op. cit., t. IX, Warszawa 1937, s. 22.

${ }^{71}$ Ibidem, t. V, s. 57; M.M. Drozdowski, Józef Pitsudski..., s. 40.

72 PDD 1919, s. 592.

${ }^{73}$ Ibidem, s. 598-593. 
17 XI 1919 r. gen. Adrian Carton de Wiart, przedstawiciel Ententy, przedstawił Naczelnikowi propozycję ofiarowania Polsce pomocy. Ameryka obiecała 100 tys. ton mąki ${ }^{74}$. Decyzja rządu warszawskiego dopłacenia do mąki amerykańskiej 300 tys. marek, żeby przyjść ludności z pomoca, miała znaczenie nie tylko aprowizacyjne, ale także polityczne ${ }^{75}$.

28 III 1919 r. na wniosek Paderewskiego sejm uchwalił przymusowa pożyczkę wewnętrzną w celu ratowania budżetu. Ministrowi skarbu Stanisławowi Karpińskiemu udało się uzyskać we Francji kredyt w wysokości 100 mln franków i w USA 14 mln dolarów. Kłopoty finansowe spowodowały kolejna zmianę na stanowisku ministra skarbu. 31 marca obją go Leon Biliński, który przeciwstawił się naprawie finansów państwa dzięki pożyczkom zagranicznym ${ }^{76}$. Do problemów z konsumpcją i wytwórczością dochodził chaos walutowy. Odbudowa wytwórczości krajowej wymagała aktywnej roli państwa w postaci pożyczek, zaliczek itd. W gabinecie Leopolda Skulskiego, powołanym 13 XII 1919 r., minister skarbu Władysław Grabski zunifikował waluty, upowszechnił markę polska, w kwietniu $1920 \mathrm{r}$. pozbawił rubla prawa obiegu w Polsce. Grabski doprowadził do finalizacji starania o pożyczkę amerykańska. Nie udało się jednak powstrzymać drukowania pieniędzy dla pokrycia wydatków państwowych ${ }^{77}$. Udzielenie pomocy materialnej Polsce leżało w interesie państw Ententy ${ }^{78}$. Apelował o to Piłsudski 15 XII 1919 r. w liście do KNP utworzonego w 1912 r. wśród emigracji polskiej w Stanach Zjednoczonych. „Waszym obowiązkiem - pisał - jest zajęcie się serdeczne losem powracającego do ojczyzny wychodźstwa, wyzyskanie wszystkich swoich wpływów w celu ułatwienia Polsce zaciagnięcia pożyczki i otrzymania wszelkich tych środków materialnych, których zniszczony wojną kraj potrzebuje"79.

Piłsudski zdawał sobie sprawę z wyzwań nowej epoki. Dał temu wyraz w przemówieniu 26 X 1919 r. w Poznaniu: „Idą czasy, których znamieniem będzie wyścig pracy, jak przed tym był wyścig żelaza, jak przed tym był wyścig krwi [wojny - J.G.]. Kto do tych zawodów bardziej przygotowany będzie, kto w tym wyścigu większe dowody wytrzymałości złoży, ten w najbliższych

${ }^{74}$ K. Świtalski, Diariusz 1919-1935, Warszawa 1992, s. 35.

75 PDD 1919, s. 590.

${ }^{76}$ M.M. Drozdowski, Józef Pitsudski..., s. 176-178; K. Badziak, op. cit., s. 170-172. Jak podał Wojciech Morawski, Polska uzyskała w latach inflacji pożyczki zagraniczne w łącznej wysokości 286,8 mln dolarów, najwięcej w 1919 r. - w wysokości 162 mln dolarów, podczas gdy w 1920 r. tylko 84 mln dolarów. W. Morawski, Od marki do złotego..., s. 76-77.

77 A. Próchnik, op. cit., s. 66-67; Gabinety Drugiej Rzeczypospolitej..., s. 58-59; M.M. Drozdowski, Józef Pitsudski..., s. 177; K. Badziak, op. cit., s. 172-202; W. Morawski, Od marki do złotego..., s. 45-61; idem, Dzieje gospodarcze Polski..., s. 177-184.

78 PDD 1919, s. 594. O pomoc zagranicy niezbędną dla odbudowy kraju i obrony przed wrogami apelował nieustannie Piłsudski m.in. w wywiadzie dla „The Daily News” 19 II 1919. M. Budny, Wywiady Pitsudskiego w prasie amerykańskiej, „Niepodległość” 1982, t. XV, s. $116-120$.

${ }^{79}$ J. Piłsudski, op. cit., t. V, s. 120. 
czasach będzie zwycięzca, ten potrafi utrzymać to, co zyskał, albo odrobić to, co stracił”. W kontekście tym podkreślał dorobek Wielkopolski w dziedzinie pracy: „Gdy myślę o zadaniach, stojacych przed Polska, chciałbym wnieść od was do Polski całą waszą namiętność pracy, który by Polskę przeniknęła, dać umiejętność zorganizowania pracy sumiennej, umiejętność pracy uczciwej" 80 .

Niewielki sektor przemysłowy miał, paradoksalnie, także dobre strony. Jak zauważył Piłsudski, niezbyt liczna klasa robotnicza sprawiła, że propaganda bolszewicka w Polsce nie miała widoków powodzenia. 18 V 1919 r. w wywiadzie dla „Journal de Genève” Naczelnik Państwa powiedział: „Z daleka bolszewizm przedstawia dla biednych i uciśnionych nadzieję lepszego jutra i uczucie zemsty socjalnej. Nie obawiam się go u nas. Nasi komuniści są zbyt słabi”. Podkreślił téz, że „nasi robotnicy są socjalistami, ale są też zaciekłymi Polakami” ${ }^{\text {. }}$

Inną zaporę przeciw bolszewizmowi stanowili drobni właściciele ziemscy, których przybywałoby dzięki reformie rolnej ${ }^{82}$. Rozwiązanie problemu głodu ziemi na wsi nie było łatwe. Po długich sporach 10 VII 1919 r. przyjęto uchwałę sejmowa (większością tylko jednego głosu) o reformie rolnej. 12 lipca utworzono Główny Urząd Ziemski ${ }^{83}$. Chociaż do ostatecznego rozstrzygnięcia należało poczekać jeszcze rok (zob. poniżej), wymowa tego aktu była jednoznaczna. 3 I 1920 r. w wywiadzie dla „Le Journal de Pologne” Piłsudski oświadczył: „Robotnicy i włościanie byli żołnierzami niepodległości i wolności. Oto dlaczego bolszewizm nie ma dzisiaj żadnych widoków na przyjęcie w Polsce" ${ }^{84}$.

Wspomniany Wierzbicki „ducha głębokiego poczucia obywatelskiego” widział też w przedstawicielach stronnictw reprezentowanych w sejmie ${ }^{85}$. Naczelnik Państwa był mniej wyrozumiały dla elit. Warunki socjalne w Polsce zmieniły się wszędzie, jednak klasy kierownicze nie uległy ewolucji. O niejednym ze swoich rodaków mógł powiedzieć, że jest to człowiek z połowy XVIII lub nawet XIX stulecia, rzadko z XX w. ${ }^{86}$ Ubolewał, że w Polsce spotyka się jeszcze poglądy feudalne i szacunek dla patriarchalnych stosunków, gdyż „robotnicy i chłopi nie moga już nosić ucisku w dwudziestym wieku”. Gdy przeprowadzano reformy socjalne, przeciwnicy mówili, że to bolszewizm. Na zarzut ten odpowiedział: „To nie bolszewizm, to nawet nie socjalizm, to demokracja. Chciałem po prostu przerzucić Polskę z osiemnastego do dwudziestego wieku". Skok ten przyczynił się do wielu trudności, lecz musiał się odbyć, gdyż „trzeba było udzielić ludowi więcej sprawiedliwości socjalnej”87.

\footnotetext{
${ }^{80}$ Ibidem, t. V, s. 117; W. Suleja, op. cit., s. 213; G. Nowik, op. cit., s. 380.

81 J. Piłsudski, op. cit., t. V, s. 89.

${ }^{82}$ Ibidem, t. V, s. 67.

${ }_{83}$ A. Próchnik, op. cit., s. 64-66; K. Badziak, op. cit., s. 212-234; M. Leczyk, op. cit., s. 174-176;

J. Pajewski, Budowa Drugiej Rzeczypospolitej..., s. 144-150.

${ }^{84}$ J. Piłsudski, op. cit., t. V, s. 131.

85 PDD 1919, s. 594.

86 J. Piłsudski, op. cit., t. V, s. 89.

${ }^{87}$ Ibidem, t. V, s. 90.
} 
Inną poważna przeszkodę $\mathrm{w}$ zjednoczeniu kraju stanowiły problemy z porozumieniem się Polaków ${ }^{88}$. Tak zwane orientacje prorosyjska, proaustriacka i proniemiecka $\mathrm{z}$ lat wojny podzieliły Polskę na obozy zwalczające się z wielka namiętnością i bezwzględnością ${ }^{89}$. Piłsudski przypomniał, że w czasach niewoli tylko niewielka część Polaków wierzyła w swoje siły i chciała za pomoca własnej pracy zdobywać dla Polski wolność. Dziś obóz ten powinien stać się jedynym obozem Polski ${ }^{90}$. Wewnętrzne spory znalazły wyraz na forum parlamentu w braku wyraźnej większości i prowadziły do niestabilnych rządów o charakterze centrowym. Gabinet Paderewskiego dotrwał do 9 XII 1919 r. 13 grudnia zastapił go centrowy rząd Skulskiego.

Proces konsolidacji był utrudniony faktem występowania w Polsce, zwłaszcza na kresach, różnych narodowości, religii i języków. O zróżnicowaniu społeczeństwa polskiego, żyjącego w warunkach wolności, świadczy dynamiczny rozwój prasy. W 1919 r. (na 1056) ukazywało się 89 tytułów prasy żydowskiej, 56 - niemieckiej, 15 - rosyjskiej, 11 - ukraińskiej, 6 - białoruskiej, 2 - litewskiej i 19 - prasy innych narodowości. W Warszawie w 1920 r. wychodziło 340 tytułów prasowych. Ogółem w $1921 \mathrm{r}$. Polska posiadała 900 tytułów prasowych, w tym ok. $20 \%$ stanowiła prasa mniejszości narodowych i wyznaniowych ${ }^{91}$. O tolerancyjnym stosunku Piłsudskiego do obywateli niepolskiej narodowości świadczą jego słowa wypowiedziane na początku kwietnia $1920 \mathrm{r}$. do delegacji Niemców mieszkających w Polsce. Przez całe życie trzymał się zasady, że „każdy naród ma prawo do ochrony swego języka i swej kultury przez państwo, do którego naród należy. [...] Demokratyczne państwo polskie chce i musi przestrzegać kulturalnych praw wszystkich swych obywateli, jestem przeciwnikiem wszelkich nienawiści i zemsty”. Przypomniał, że był naczelnikiem państwa konstytucyjnego o ograniczonej władzy. „Ale leży to w mojej mocy, żeby przyczynić się do zgodnego współżycia obu narodowości, polskiej i niemieckiej w Państwie polskim"92.

Zmian potrzebowano $\mathrm{w}$ Polsce, ale sens miały tylko zmiany na lepsze ${ }^{93}$. Zdaniem Piłsudskiego było to możliwe tylko w sytuacji okazywania sobie szacunku i zaufania oraz współpracy wszystkich wyznań, stanów i narodowości. Przypominał, że „rząd nie jest wszechmogący. Chciałbym, aby rząd mógł się oprzeć na ludności. Wtedy da wam to, czego od niego żądacie" ${ }^{94}$.

${ }^{88}$ M. Tarnowska, Przyszłość pokaże... Wspomnienia, Łomianki 2012, s. 94-95; A. Friszke, op. cit., s. $63-64$.

89 J. Piłsudski, op. cit., t. V, s. 120-121.

${ }^{90}$ Ibidem, t. V, s. 121.

${ }^{91}$ M.M. Drozdowski, Józef Pitsudski..., s. 200-201; M. Leczyk, op. cit., s. 106-118.

92 J. Piłsudski, op. cit., t. V, s. 155.

${ }^{93}$ Kazimierz Świtalski zanotował 10 VI 1920 r.: „Celem polityki wewnętrznej Komendanta było zawsze doprowadzenie do Polski demokratycznej bez wstrzaśnień, dopóki takie lub inne rozwiązania społeczne na Zachodzie nie będą gotowe”. K. Świtalski, Diariusz $1919-1935 \ldots$, s. 49.

${ }_{94}$ J. Piłsudski, op. cit., t. V, s. 133, Przemówienie w Łucku 10 I 1920 r. 
Zadeklarował publicznie swoje credo: „jako Naczelnik Państwa, nie moge być naczelnikiem ani żadnej grupy lub stronnictwa, ani też jakiegokolwiek miasta; jestem Naczelnikiem całego narodu i wszystkich jego warstw" ${ }^{95}$.

W przemówieniu wygłoszonym 11 I $1920 \mathrm{r}$. w Lublinie powrócił do wątku podziałów wśród Polaków, które były jednym z przekleństw budownictwa państwowego ${ }^{96}$. Ubolewał, „żeśmy się podzielili na kilka rodzajów Polaków, że mówimy jednym polskim językiem, a inaczej nawet słowa polskie rozumiemy, żeśmy wychowali wśród siebie Polaków różnych gatunków, Polaków z trudnością się porozumiewających, Polaków, tak przyzwyczajonych do życia według obcych szablonów, według obcych narzuconych sposób życia i metod postępowania, żeśmy prawie je za swoje uznali, że wyrzec się ich z trudnością możemy"97. Dlatego tak ważne było zwalczanie partykularyzmu. „Polska, jeżeli chce być silną nie na uroczystościach, nie przy kielichu wina, lecz w codziennej pracy, w codziennym życiu, w codziennych wspólnych kłopotach, w codziennym słuchaniu ogólnych i zjednoczonych praw, Polska musi być zjednoczona i Polska musi być jednościa" ${ }^{98}$.

W okresie zmagań wojennych z Rosja sowiecką i marszu Armii Czerwonej przez ziemie polskie rozgorzała walka propagandowa, wybuchały strajki organizowane przez komunistów. Nie brakowało przykładu oporu społeczeństwa. Gdy w czasie kryzysu gabinetowego w czerwcu 1920 r. (zob. poniżej) wybuchł strajk pracowników zakładów użyteczności publicznej w Warszawie, mieszkańcy przeciwstawili mu się spontanicznie. Powołali Stowarzyszenie Samopomocy Społecznej, aby nie dopuścić do paraliżu gospodarki komunalnej w mieście ${ }^{99}$. W ocenie Piłsudskiego mobilizacja społeczeństwa wobec śmiertelnego zagrożenia w lipcu 1920 r. pozostawiała wiele do życzenia ${ }^{100}$. Na łamach prasy pisano, że „w społeczeństwie panuje jakaś starczość, jakieś zamiłowanie w jałowych narzekaniach i biadaniach"101. 3 lipca Naczelnik Państwa wydał odezwę, w której wzywał społeczeństwo do współdziałania i pomocy żołnierzom. Wysiłki Piłsudskiego i przedstawicieli administracji państwowej przyniosły skutek i powoli następowały zmiany w nastrojach. Przyczyniły się one też do wznowienia dyskusji o reformie rolnej. Mimo że ziemianie stawiali opór ${ }^{102}$, 15 VII 1920 r. sejm, tym razem jednomyślnie, przyją ustawę

${ }_{95}$ Ibidem, t. V, s. 135.

${ }^{96}$ Ibidem, t. V, s. $136-138$.

${ }_{97}$ Ibidem, t. V, s. 136.

${ }^{98}$ Ibidem, t. V, s. 137.

${ }_{99}$ M.M. Drozdowski, Józef Pitsudski..., s. 230-231.

100 Świtalski zapisał w diariuszu 17 VII 1920 krytyczną ocenę Komendanta, że „społeczeństwo zaczyna się dopiero trochę kiwać, ale ono nie jest jeszcze wcale rozbujane w swym zapale”. K. Świtalski, Diariusz. Uzupetnienie z lat 1919-1932, przedmowa i przygotowanie do druku P. Duber, W. Suleja, Warszawa 2012, s. 35.

${ }^{101}$ M.M. Drozdowski, Józef Pitsudski..., s. 230-231.

${ }^{102}$ Gdy 22 VI 1920 r. na porządku dziennym stanęła sprawa reformy agrarnej, Świtalski zanotował, że „obszarnicy chcieliby, by pod tym względem im pozostawić inicjatywę. Być 
o wykonaniu reformy rolnej ${ }^{103}$. Piłsudski był spokojny o siłę armii polskiej, lecz zdawał sobie sprawę ze słabości gospodarczych i konieczności uzyskania pomocy od koalicji ${ }^{104}$. Potrzeby armii prowadzącej wojnę z Rosją sowiecką były tak wielkie, że w pierwszym kwartale 1920 r. udział wydatków wojskowych przekroczył 62\% całego budżetu. 13 VII 1920 r. Główny Komitet Daru Narodowego postanowił przelać wszystkie fundusze na cele obrony państwa ${ }^{105}$.

Nawet zagrożenie ze strony Rosji sowieckiej nie wyciszyło sporów wewnętrznych i nie powstrzymało przeciwników Piłsudskiego od politycznej ofensywy. W sejmie zaatakowano gabinet Skulskiego i w jego miejsce powołano 23 czerwca rząd Władysława Grabskiego (23 czerwca - 24 VII 1920) ${ }^{106}$. W ogniu krytyki znalazł się także Naczelnik Państwa. Atakowano go zwłaszcza za kampanię kijowską i politykę ukraińska. Wielką rolę w nagonce odgrywali publicyści związani z Narodową Demokracją: Stanisław Stroński i Adolf Nowaczyński. 19 lipca na posiedzeniu Rady Obrony Państwa (ROP) Dmowski wspierany przez prawicowych polityków i generałów domagał się zmian personalnych w wojsku i w rządzie oraz zdjęcia Piłsudskiego ze stanowiska Naczelnego Wodza. Starania te zakończyły się porażka, a Naczelnik uzyskał od ROP pełne zaufanie ${ }^{107}$. W obliczu zagrożenia wywołanego zbliżaniem się Armii Czerwonej do Warszawy doszło do większej konsolidacji politycznej. 24 VII 1920 r. powstał rząd koalicyjny od lewicowej PPS po prawicowy Związek Ludowo-Narodowy z premierem Wincentym Witosem i wicepremierem Ignacym Daszyńskim. Jednak w dalszej fazie zwycięskiej wojny polsko-bolszewickiej potęgowały się różnice poglądów i od koalicji zaczęły odpadać kolejne stronnictwa (narodowi demokraci wystapili z rządu w listopadzie 1920, socjaliści w grudniu 1920, a PSL „Wyzwolenie” w lutym 1921) ${ }^{108}$. Udana mobilizacja społeczeństwa z udziałem Piłsudskiego, Witosa i Daszyńskiego przyniosła krótkotrwałe rezultaty. Wystarczyła do pokonania Armii Czerwonej, lecz nie do ustanowienia pokoju społecznego i utemperowania konfliktów politycznych.

może, że jest to gra na zwłokę. Osmołowski [Jerzy] chce, by w tym roku w każdym powiecie choćby jeden majątek został rozparcelowany. Sama ludność domaga się energicznie przede wszystkim parcelacji majątków rosyjskich”. K. Świtalski, Diariusz. Uzupetnienie..., s. 56.

${ }^{103}$ S. Kutrzeba, op. cit., s. 165-169; M. Leczyk, op. cit., s. 176-177.

104 J. Piłsudski, op. cit., t. V, s. 109.8 X 1919 r. w wywiadzie dla korespondenta „Timesa”. J. Rakowski, Gospodarcze zaplecze wojny polsko-bolszewickiej, „Niepodległość” 1992, t. XXV, s. 233-238.

105 J. Piłsudski, op. cit., t. V, s. 164-165; J. Rakowski, op. cit., s. 230-233.

106 K. Świtalski, Diariusz 1919-1935..., s. 50; A. Próchnik, op. cit., s. 72-74; Gabinety Drugiej Rzeczypospolitej..., s. 63-68; M.M. Drozdowski, Józef Pitsudski..., s. 230.

107 J. Pajewski, Budowa Drugiej Rzeczypospolitej..., s. 67-69. W materiałach źródłowych występuja przesłanki sugerujące organizowanie przez ugrupowania prawicowe 4 VIII 1920 zamachu na Piłsudskiego. J. Cisek, O planie zamachu na Józefa Piłsudskiego $w$ sierpniu 1920 roku, „Niepodległość” 1991, t. XXIV, s. 7-14; W. Suleja, op. cit., s. 234-236, 241-242.

108 Gabinety Drugiej Rzeczypospolitej..., s. 72-78; Cz. Brzoza, A.L. Sowa, op. cit., s. 261; W. Suleja, op. cit., s. 235. 
Piłsudski w sierpniu 1920 r. ocenił jednoznacznie sytuację społeczną w Polsce: „Nasze społeczeństwo nie łatwo rozgrzać - już stygnie”109.

Po Cudzie nad Wisłą zmagania wojenne z Rosja sowiecka przenosiły się dalej na wschód. Pozostały ogromne zniszczenia. 15 IX 1920 r. w wywiadzie dla gazety „Le Temps” Piłsudski mówił o konieczności wielkiej pracy organizacyjnej i wyzyskania zasobów naturalnych, co było możliwe tylko w warunkach pokoju. Zaznaczył pragnienie utrzymania dobrych stosunków ze wszystkimi sasiadami ${ }^{110}$.

\section{Zepsuci niepodległością (październik 1920 - grudzień 1922)}

18 X 1920 r. w rozkazie na zakończenie wojny i wstrzymania działań wojennych Piłsudski obiecał, że żołnierze, którzy tyle zrobili dla Polski, nie zostaną bez nagrody. Zaproponował rządowi, aby „część zdobytej ziemi została własnościa tych, co ją polską zrobili, uznoiwszy ją polską krwią i trudem niezmiernym"111. Nadawanie działek miało związek z parcelacja gdzie mimo trudności nastapił postęp. W 1921 r. na ogólną liczbę ok. 3,5 mln gospodarstw rolnych 29\% nie posiadało więcej niż 2 ha, a $33 \%$ - od 2 do 5 ha (razem obie grupy zajmowały $14 \%$ powierzchni gruntów rolnych). Własność powyżej 5 ha obejmowała 36,5\% gruntów rolnych ${ }^{112}$. Zmiana tego stanu rzeczy napotkała opór warstwy ziemiańskiej powołującej się na przepisy konstytucji o nienaruszalności własności prywatnej. Na podstawie reformy rolnej rozparcelowano ponad pół miliona hektarów ziemi: w 1921 r. - 180,4 tys. ha, a w 1922 r. $-254,2$ tys. ha gruntów. W ramach repolonizacji byłego zaboru pruskiego wywłaszczono za odszkodowaniem 3,8 tys. osad kolonistów niemieckich oraz przejęto 200 folwarków państwowych. Na ziemiach byłego zaboru rosyjskiego przejęto byłe carskie dobra państwowe. Zgodnie z zapowiedziami pierwszeństwo mieli zdemobilizowani żołnierze i inwalidzi wojenni oraz robotnicy rolni. Ponad 22 tys. żołnierzy otrzymało działki w województwach wschodnich. W wyniku aktywnej polityki rolnej malał obszar odłogów: na przełomie 1918 i 1919 - 4,6 mln ha, w 1920 - 3,5 mln, a w 1923 - 370 tys. ha. Przyniosło to wymierne korzyści i w latach 1921-1922 zlikwidowano deficyt zbóż, a w następnym roku powstały nadwyżki, co pozwoliło znieść w drugiej połowie $1921 \mathrm{r}$. reglamentację żywności ${ }^{113}$.

Polska była krajem rolniczo-przemysłowym. W 1921 r. 63,8\% ludności pracowało $\mathrm{w}$ rolnictwie i leśnictwie, $17,2 \%$ - w przemyśle i rzemiośle, $6,2 \%$ - w handlu i ubezpieczeniach, 3,7\% - w służbie publicznej,

${ }^{109}$ J. Piłsudski, op. cit., t. V, s. 167.

${ }^{110}$ Ibidem, t. V, s. 170.

111 Ibidem, t. V, s. 175-176.

${ }_{112}$ M.M. Drozdowski, Józef Pitsudski..., s. 283.

${ }^{113}$ Idem, Życie gospodarcze Polski w latach 1918-1939, w: Z dziejów Drugiej Rzeczypospolitej, red. A. Garlicki, Warszawa 1986, s. 150-151; G. Nowik, op. cit., s. 386. 
3,4\% - w transporcie ${ }^{114}$. Wzrastała liczba osób zatrudnionych w przemyśle. Na przełomie 1918 i 1919 r. w dawnej Kongresówce do pracy zostało przyjętych tylko ok. 40 tys. osób, w połowie 1919 - 90 tys., w końcu tego roku - 125 tys., w 1920 - 202 tys., w 1921 - 356 tys., a w $1922-471$ tys. ${ }^{115}$ Od czerwca $1921 \mathrm{r}$. zaczęła obowiązywać zasada wolnego handlu z zagranica. Trwała odbudowa zniszczeń wojennych. Zmniejszyła się liczba bezrobotnych. Produkcja w wielu działach zbliżyła się do poziomu przedwojennego. Latem 1920 r. gen. Kazimierz Sosnkowski, wiceminister spraw wojskowych, zaproponował budowę portu wojennego i rybackiego w Gdyni. 23 IX 1922 r. zapadła historyczna decyzja.

W połowie 1922 r. Piłsudski przedstawił optymistyczna sytuację gospodarczą Polski. „Ani jeden funt zboża nie wchodzi do nas z zewnątrz, a kto wie, czybyśmy nawet, nie odejmujacc sobie od ust, nie mogli innym odstapić ze swego”. Całkowicie zmienił się wygląd kolei. Kwestia bezrobocia, „tak ciężka, gdzie indziej, jak rak nieraz tocząca życie społeczne, u nas prawie nie istnieje. Mogliśmy bez żadnych wahań, bez żadnych spóźnień zdemobilizować po skończonej wojnie w jednej chwili blisko milion żołnierzy"116. Naczelnik Państwa nie tuszował jednak rzeczywistości. W przemówieniu wygłoszonym na otwarcie sejmu 28 XI 1922 r. do najważniejszych wyzwań zaliczył potrzebę uregulowania finansów państwa. Niewielka pociechą było to, że z deficytem budżetowym, zwiększonym obiegiem banknotów, a także wzrostem cen żywności oraz cen hurtowych zmagała się cała powojenna Europa.

Lata 1921-1922 to okres inflacyjnego ożywienia gospodarczego. Z inflacji korzystało przede wszystkim państwo, dzięki tzw. podatkowi inflacyjnego, który z wolna stał się najważniejszym źródłem dochodów i w latach 1918-1923 zapewniał 64-78\% całości wpływów budżetowych ${ }^{117}$. Rząd Witosa był bezradny wobec postępujacej inflacji. Minister skarbu Jan Kanty Steczkowski zrezygnował z postulowanej pożyczki przymusowej i bezskutecznie usiłował zmniejszyć deficyt budżetowy za pomoca pożyczek zagranicznych ${ }^{118}$. Walkę z inflacją kontynuował minister skarbu w rządzie Antoniego Ponikowskiego, Jerzy Michalski ${ }^{119}$. Zgodnie z projektem ustawy złożonej w sejmie $7 \mathrm{X}$ 1921 r. naprawa finansów miała być oparta na aktywizacji życia gospodarczego (m.in. wydłużenie czasu pracy) oraz na działaniach administracyjnych i finansowych. 15 XII 1921 r. przyjęto ustawę o powszechnej daninie majątkowej i utworzono 1 VI 1922 r. monopol tytoniowy. Po załamaniu się kursu marki w styczniu 1922 r. Michalski wzorem Steczkowskiego widział ratunek

\footnotetext{
114 J. Żarnowski, Społeczeństwo Drugiej Rzeczypospolitej 1918-1939, Warszawa 1973, s. 22.

115 M.M. Drozdowski, Życie gospodarcze Polski..., s. 149; G. Nowik, op. cit., s. 385.

116 J. Piłsudski, op. cit., t. V, s. 277.

117 S. Kutrzeba, op. cit., s. 176-180; M. Leczyk, op. cit., s. 130-131; Cz. Brzoza, A.L. Sowa, op. cit., s. $176-177$.

118 M.M. Drozdowski, Józef Pitsudski..., s. 287.

119 I gabinet Ponikowskiego istniał od 19 IX 1921 do 5 III 1920. Gabinety Drugiej Rzeczypospolitej..., s. 79-85.
} 
w pożyczkach zagranicznych. Próby uzyskania środków z Francji i USA nie dały jednak rezultatu ${ }^{120}$. Skutki inflacji odczuwali szczególnie najubożsi oraz skazani na stałe dochody, m.in. urzędnicy państwowi. Konieczność prowadzenia oszczędności spowodowała likwidację 18 II 1922 r. Ministerstwa Kultury i Sztuki. Pauperyzacja środowisk twórczych ograniczała rozwój kultury polskiej.

Piłsudski był świadomy trudności wynikających z powstania nowej Europy, niepodobnej do przedwojennej, milionów ludzi rzuconych na nieznane im życie, nowych państw wytrąconych z dotychczasowych systemów gospodarczych. Nie tylko przed Polska, ale przed cała Europa stał „problem, wytworzony nowym życiem, powstałym na gruzach starego życia"121. Nikt nie zdawał sobie sprawy, że pojawiające się nowe radykalne rozwiązania problemów, proponowane przez komunizm, faszyzm i nazizm, doprowadzą Europę w ciagu zaledwie niespełna 20 lat na skraj przepaści. Nie będą w stanie powstrzymać tego procesu ani demokratyczne państwa Zachodu, ani autorytarne reżimy Europy Środkowej, w tym także Polska.

Jak wynikało z pierwszego spisu powszechnego w 1921 r., na terytorium państwa mieszkało 27176 tys. osób. W strukturze społeczeństwa dominowali chłopi (53,3\%), robotnicy $(27,6 \%)$, drobnomieszczaństwo (11,0\%), inteligencja i pracownicy umysłowi $(5,1 \%)$, burżuazja $(1,1 \%)$, ziemianie $(0,4 \%)^{122}$. Nadal trwały powroty ludności polskiej. Przez punkty kontrolne, nadzorowane przez Urząd ds. Powrotu Jeńców, Uchodźców i Robotników, przeszło w 1921 r. 482 tys., a w 1922 - 279 tys. osób.

Państwo polskie, zdaniem Piłsudskiego, miało szansę stać się ostoją ładu i porządku na wschodzie Europy, a nawet zyskać mocarstwowe znaczenie. Warunkiem tego było ustalenie „oględnej polityki”, która „zdoła ją ustrzec od wstrząsów i przesileń, osłabiających tempo konsolidacji wewnętrznej, hamujaccych tok pracy nad organizacja państwa". Ten warunek Piłsudski nazwał umiejętnością znalezienia w życiu państwowym „zdrowej, rozumnej przeciętnej" ${ }^{23}$. Z tym było jednak coraz trudniej w związku z konfliktami społecznymi i politycznymi. Piłsudski znał ich przyczynę. 5 VIII 1922 r. wypowiedział znamienne słowa: „Jesteśmy już teraz prawdopodobnie czteroletnim życiem niepodległym zepsuci" ${ }^{24}$. Walka polityczna dotyczyła nie tylko bieżącej polityki,

120 S. Kutrzeba, op. cit., s. 180-182; M.M. Drozdowski, Józef Pitsudski..., s. 294-295; W. Morawski, Od marki do złotego..., s. 61-68; idem, Dzieje gospodarcze Polski..., s. 183-184.

121 J. Piłsudski, op. cit., t. V, s. 278.

${ }^{122}$ Encyklopedia historii Drugiej Rzeczypospolitej, Warszawa 1999, s. 415; M. Leczyk, op. cit., s. $118-126$.

${ }^{123}$ Tok rozmyślań Piłsudskiego o roli Polski w przyszłej Europie, sformułowany podczas internowania w Magdeburgu, przedstawił K. Sosnkowski, „Z Legionów do Magdeburga”, w: Za kratami więzień i drutami obozów (Wspomnienia i notatki więźniów ideowych z lat 1914-1921), t. II, zebrał i oprac. W. Lipiński i in., Warszawa 1928, s. XXVIII-XXIX; S. Skwarczyński, Rozważania ideologiczne, „Niepodległość” 1976, t. X, s. 10.

124 J. Piłsudski, op. cit., t. V, s. 264. 
ale także kwestii ustrojowych. Praca nad konstytucją trwała długo, bo aż do marca $1921 \mathrm{r}$. Główna przyczynę stanowiły nie poszukiwanie doskonałych rozwiązań, lecz bieżące potrzeby polityczne: popieranie lub zwalczanie polityki Naczelnika Państwa. Konstytucja marcowa była demokratyczna i gwarantowała obywatelom podstawowe wolności. Osiagnięty kompromis dawał jednak sejmowi, oprócz władzy ustawodawczej, również silny wpływ na całą administrację. Jak pisał Stanisław Kutrzeba, „przy wszystkich zaletach - wielka jej wadą było to, że ograniczając prezydenta Rzeczypospolitej omalże tylko do reprezentacji, nie zabezpieczyła większej trwałości i jednolitości rządu"125.

Sejm Ustawodawczy zamiast się rozwiązać po uchwaleniu konstytucji, pracował nadal, przyczyniając się do chaosu na szczytach władzy ${ }^{126}$. Słabnący rząd Witosa dotrwał do połowy września $1921 \mathrm{r}$. Zastapił go 19 IX $1921 \mathrm{r}$. gabinet pozaparlamentarny z Ponikowskim na czele. Do jego upadku w marcu 1922 r. doprowadziły spory o status Wileńszczyzny przyłączonej do Polski. Ponikowski staną ponownie 10 marca na czele zrekonstruowanego gabinetu, ale ustapił 6 VII 1922 r. pod wpływem krytyki Naczelnika Państwa, który zarzucił mu nieudolność w prowadzeniu polityki wewnętrznej i zagranicznej (traktat niemiecko-sowiecki w Rapallo) ${ }^{127}$. Upadek rządu Ponikowskiego spowodował dwumiesięczne przesilenie rządowe i doprowadził do konfrontacji między Piłsudskim a Narodową Demokracją o zakres kompetencji Naczelnika Państwa. Wniosek postawiony w sejmie przez prawicę o wyrażenie mu nieufności został odrzucony 26 lipca niewielką przewaga głosów. Ostatecznie spór zakończył się zwycięstwem Piłsudskiego, który powołał rząd z Julianem Nowakiem na czele (31 lipca - 16 XII 1922) ${ }^{128}$. Piłsudski twierdził, że ani wojna z bolszewikami, ani zagrożenia zewnętrzne nie dały mu się tak we znaki, jak walka z sejmem w atmosferze pełnej nienawiści i podłości. We wrześniu 1922 r. oświadczył dosadnie: „W Polsce jestem ciagle zwierzyną w klatce, do której każdy śmierdziuch strzelać może... lecz mniejsza z tym. Najwstrętniejsze przeszedłem i mam to za soba, niech inni się z tym parają. Cztery lata!"129.

125 S. Kutrzeba, op. cit., s. 169-175; A. Próchnik, op. cit., s. 84-88; W. Suleja, op. cit., s. 254; J. Pajewski, Budowa Drugiej Rzeczypospolitej..., s. 112-124; G. Nowik, op. cit., s. 317-327.

126 J. Pajewski, Budowa Drugiej Rzeczypospolitej..., s. 53-54.

${ }^{127}$ Gabinety Drugiej Rzeczypospolitej..., s. 87-93; A. Garlicki, op. cit., s. 364-367; W. Suleja, op. cit., s. 255-259.

128 S. Kutrzeba, op. cit., s. 194-196; A. Próchnik, op. cit., s. 95-106; Gabinety Drugiej Rzeczypospolitej..., s. 95-104; W. Suleja, op. cit., s. 258-259; Cz. Brzoza, A.L. Sowa, op. cit., s. 261-262.

${ }^{129}$ W. Baranowski, op. cit., s. 89-90; W. Jędrzejewicz, J. Cisek, Kalendarium życia Józefa Pitsudskiego 1867-1935, t. III: 1921-1926, Kraków-Łomianki 2007, s. 138. Negatywna opinię o Sejmie Ustawodawczym miał też gen. Józef Dowbor-Muśnicki. Latem 1919 r. zwrócił się do szefa Sztabu Generalnego gen. Stanisława Hallera z propozycją „skłonienia Piłsudskiego do rozwiązania Sejmu dla położenia kresu demagogii i dezorientacji ludności”, obiecując udzielić poparcia Naczelnikowi Państwa. J. Dowbor-Muśnicki, Moje wspomnienia, Poznań 2013, s. 505-507. 
W sierpniu 1922 r. Piłsudski zadał z pozoru optymistyczne pytanie: „Więc czyż można przypuszczać, że Polska, wychodząc zwycięsko z tak ciężkiej próby, przełamując ciężkie nieraz przeszkody, nie będzie dawała sobie rady w łatwiejszych warunkach?”"130. Istniały powody, żeby wierzyć w państwo polskie. Granice państwa były ustalone i nikt nie miał w planach szukania konfliktu z sasiadami. Przeciwnicy Piłsudskiego oskarżyli go jednak w czerwcu 1922 r. o dążenie do wojny, czemu zaprzeczył Medard Downarowicz w oświadczeniu opublikowanym 11 czerwca w „Kurierze Porannym”: „Polska nie myśli atakować; byłoby to nonsensem politycznym i strategicznym [...] Wtracanie $\mathrm{w}$ wojnę społeczeństwa o słabej strukturze moralnej byłoby najgorszym absurdem"131. W przemówieniu wygłoszonym na otwarcie sejmu 28 XI $1922 \mathrm{r}$. Piłsudski apelował o zachowanie w stosunkach międzynarodowych spokoju, „dla którego dostateczna podstawę stanowi zarówno wiara we własne siły, jak i zaufanie do sojuszników i przyjaciól, których posiadamy, a którym Polska ze swej strony danego słowa dotrzymać potraf”"132.

Największe zagrożenia dla stabilności państwa tkwiły w kraju. Ostra walka polityczna przed wyborami zaplanowanymi na 5 XI 1922 r. do sejmu i 12 listopada do senatu nie zapowiadała niczego dobrego. Prawica gwałtownie zwalczała ugrupowania centrowe jako rzekomo niepotrzebne ${ }^{133}$. Wybory wygrał Chrześcijański Związek Jedności Narodowej (29,1\%), chociaż do zapewnienia sobie większości potrzebował ludowców z PSL „Piast” $(13,2 \%)^{134}$. Zdając sobie sprawę z konsekwencji „przekleństwa podziałów”135, Piłsudski w przemówieniu na otwarcie sejmu 28 listopada zwrócił się z apelem, aby posłowie przykładem swoim potwierdzili, „że w naszej ojczyźnie istnieje możność lojalnej współpracy ludzi, stronnictw i instytucji państwowych"136. Od senatu oczekiwał, że będzie „rzecznikiem rozsądku, rozwagi i miary przy spełnianiu zadań, poruczonych naczelnym organom władzy państwowej”. Wyraził tė̇ życzenie, aby senat jako instytucja państwowa reprezentująca umiar stawała „w ciężkim zadaniu współpracy zawsze po stronie tych, którzy czy to z urzędu, czy ze skłonności łagodzą tarcia, zmniejszaja konflikty i doprowadzają do koniecznej równowagi zamierzeń, celów i środków"137.

${ }^{130}$ J. Piłsudski, op. cit., t. V, s. 277.

${ }^{131}$ W. Jędrzejewicz, J. Cisek, op. cit., s. 113. Piłsudski podtrzymał w maju 1926 r. pogląd, że w odrodzonym państwie nie nastapiło odrodzenie duszy narodu, z wyjatkiem walki orężnej, co umożliwiło doprowadzenie wojny do zwycięskiego końca. W innych dziedzinach miały miejsce „znikczemnienie ludzi”, nadużywanie swobód demokratycznych, przewaga interesu partyjnego skierowanego przeciw reprezentantom państwa. J. Piłsudski, op. cit., t. IX, s. 31.

${ }^{132}$ Ibidem, t. V, s. 283.

${ }^{133}$ S. Kutrzeba, op. cit., s. 169-175.

${ }^{134}$ Ibidem, s. 196-197; A. Próchnik, op. cit., s. 107-113.

135 J. Piłsudski, op. cit., t. V, s. 136.

136 Ibidem, t. V, s. 284.

${ }^{137}$ Ibidem, t. V, s. 285-286; W. Suleja, op. cit., s. 261-262. 
Apel Naczelnika Państwa pozostał bez odzewu. Piłsudski zrezygnował z kandydowania na urząd prezydenta. Po wyborze 9 XII 1922 r. Gabriela Narutowicza, także głosami mniejszości narodowych, prawica rozpętała przeciw niemu bezprzykładną nagonkę. Narutowicz dostrzegł właściwości polskiego życia politycznego, których wcześniej nie widział: „Zdziczenie obyczajów, nabyte w długiej niewoli, zepsucie moralne pod wpływem długiej wojny, nieprzebieranie w żadnych środkach, bezwzględność w stosunku do czci i honoru każdego człowieka, brak szacunku zarówno dla siebie, jak i dla pracy" ${ }^{138}$. Narutowicz musiał w końcu przyznać rację Piłsudskiemu bezwzględnemu w swoich sądach o Polakach: „Ma pan racje [...] to nie jest Europa. Ci ludzie lepiej się czuli pod tymi, kto karki im deptał i bił po pysku" ${ }^{139}$. Na powstrzymanie fali nienawiści było już za późno i pierwszy prezydent Rzeczypospolitej Polskiej został zamordowany 16 XII 1922 r. ${ }^{140}$

„Upojenie wolnością" pozwoliło odbudować państwo polskie, ustalić i obronić jego granice oraz powstrzymać ekspansję bolszewików, nie tylko ideologiczna, ale także militarna, w wyniku zwycięstwa w wojnie z Rosją sowiecka. „Upojenie wolnością nie wystarczyło jednak do przezwyciężenia trudności gospodarczych i podziałów społecznych oraz uczynienia z Polski jedności, o co zabiegał Naczelnik Państwa. Narodowym demokratom, wykorzystującym bez skrupułów łatwowierność Polaków, udało się wyeliminować Marszałka z życia politycznego. Zapłaciła za to polska demokracja parlamentarna kilka lat później, po zamachu majowym Piłsudskiego w 1926 r. i ustanowieniu porządku autorytarnego.

\section{Streszczenie}

Odbudowa państwa polskiego po odzyskaniu niepodległości postępowała w ramach wyznaczonych przez powojenny chaos społeczno-gospodarczy i euforię po odzyskaniu niepodległości w czasie rządów Naczelnika Państwa realizującego podstawowe reformy jako zapory przeciwko radykalizmowi lewicowemu i prawicowemu (11 XI 1918 - 26 I 1919); rządów Sejmu Ustawodawczego i Naczelnika Państwa o kompetencjach ograniczonych na gruncie Małej Konstytucji oraz chwilowej konsolidacji „stygnącego społeczeństwa” w czasie wojny polsko-bolszewickiej (26 I 1919 - październik 1920); wyrastania z euforii niepodległościowej i konfliktów prowadzących do odmowy Piłsudskiego kandydowania na urząd prezydenta, zabójstwa prezydenta Gabriela Narutowicza i złożenia urzędu Naczelnika Państwa (listopad 1920 - grudzień 1922).

138 J. Piłsudski, op. cit., t. VI, s. 52; W. Suleja, op. cit., s. 254-265.

139 J. Piłsudski, op. cit., t. VI, s. 56. Piłsudski dobrze oceniał Narutowicza, ale nie miał złudzeń, co go czeka po przyjeździe z emigracji do ojczyzny. Pod koniec grudnia 1918 r. oświadczył Władysławowi Baranowskiemu: „Człowiek Zachodu mówicie... Tym ludziom jednak w Polsce zawsze najciężej, trudno oswoić się i przyzwyczaić. Napiszcie jednak, przestrzeżcie i powiedzcie, co tu się dzieje i jak ja tu walczę". W. Baranowski, op. cit., s. 53.

140 A. Próchnik, op. cit., s. 122-130; S. Thugutt, op. cit., s. 141-147. 
„Upojenie wolnością” pozwoliło odbudować państwo polskie, ustalić i obronić jego granice oraz powstrzymać ekspansję bolszewików, nie tylko ideologiczna, ale także militarna, w wyniku zwycięstwa w wojnie z Rosją sowiecka. „Upojenie wolnością” nie wystarczyło jednak do przezwyciężenia trudności gospodarczych i podziałów społecznych oraz uczynienia z Polski jedności, o co tak zabiegał Naczelnik Państwa. Narodowym demokratom, wykorzystującym bez skrupułów łatwowierność Polaków, udało się wyeliminować Marszałka z życia politycznego (grudzień 1922 - czerwiec 1923). Zapłaciła za to polska demokracja parlamentarna kilka lat później, po zamachu majowym Piłsudskiego w 1926 r. i ustanowieniu porządku autorytarnego.

\section{"An Inebriation with Freedom" and Social and Economic Conditions of the Recon- struction of the Polish State under Chief of State Józef Piłsudski, 1918-1922}

The reconstruction of the Polish state in 1918 was taking place in the conditions of post-war socio-economic chaos and euphoria after Poland regained independence under the rule of the Chief of State who implemented basic reforms as barriers against left- and right wing radicalism (11 November 1918 - 26 January 1919); the rule of the Legislative Sejm and the Chief of State with his authority restricted by the so-called Small Constitution and temporary consolidation of the "cooling down society" during the Polish-Bolshevik War (26 January 1919 - October 1920); the period of outgrowing the independence euphoria and of conflicts leading to Piłsudski's refusal to run for president, the assassination of President Gabriel Narutowicz, and resignation from the office of Chief of State (November 1920 - December 1922).

"An Inebriation with Freedom" made it possible to reconstruct the Polish state, to draw up and defend its borders, and to stop the expansion of the Bolsheviks, not only ideological one, but also the military in the war with Soviet Russia. But this inebriation was not enough to overcome economic problems and social divisions, and to unite Poland which was the aim of the Chief of State. National democrats, unscrupulously taking advantage of the credulity of Polish people, were able to eliminate the Marshal from political life (December 1922 - June 1923). The price was paid by the Polish parliamentary democracy several years later, after Piłsudski's May Coup in 1926 and the establishment of the authoritarian rule.

\section{Bibliografia}

Ajnenkiel A., Od rzadów ludowych do przewrotu majowego. Zarys dziejów politycznych Polski 1918-1926, Warszawa 1978.

Badziak K., W oczekiwaniu na przełom. Na drodze od odrodzenia do załamania państwa polskiego listopad 1918 - czerwiec 1920, Łódź 2004.

Bartoszewicz H., Dzieje pierwszych dwudziestu miesięcy II Rzeczypospolitej czy monografia gabinetu Leopolda Skulskiego?, „Dzieje Najnowsze” 2008, nr 2, s. 134-145.

Brauneder W., Die Verfassungssituation 1918: ein Staat entsteht, ein Staat geht unter, w: Österreich. 90 Jahre Republik. Beitragsband der Ausstellung im Parlament, red. S. Karner, L. Mikoletzky, Innsbruck-Wien-Bozen 2008, s. 15-23.

Brzoza Cz., Sowa A.L., Historia Polski 1918-1945, Kraków 2006.

Budny M., Wywiady Piłsudskiego w prasie amerykańskiej, „Niepodległość” 1982, t. XV, s. $116-120$.

Cisek J., O planie zamachu na Józefa Pitsudskiego w sierpniu 1920 roku, „Niepodległość” 1991, t. XXIV, s. 7-14.

Drozdowski M.M., Ignacy Jan Paderewski. Zarys biografii politycznej, Warszawa 1979.

Drozdowski M.M., Józef Piłsudski. Naczelnik Państwa Polskiego 14 XI 1918 - 14 XII 1922, Warszawa 2008. 
Drozdowski M.M., Życie gospodarcze Polski w latach 1918-1939, w: Z dziejów Drugiej Rzeczypospolitej, red. A. Garlicki, Warszawa 1986, s. 146-176.

Encyklopedia historii Drugiej Rzeczypospolitej, Warszawa 1999.

Friszke A., O ksztatt niepodlegtej, Warszawa 1989.

Gabinety Drugiej Rzeczypospolitej, red. J. Faryś, J. Pajewski, Poznań 1991.

Jakubowska U., Publicystyka Narodowej Demokracji wobec Józefa Piłsudskiego w okresie międzywojennym, w: Pitsudski na tamach $i$ w opiniach prasy polskiej 1918-1989, red. M. Jabłonowski, E. Kossewska, Warszawa 2005, s. 97-118.

Jędrzejewicz W., Cisek J., Kalendarium życia Józefa Piłsudskiego 1867-1935, t. III: 1921-1926, Kraków-Łomianki 2007.

Kutrzeba S., Polska odrodzona, Kraków 1988.

Landau Z., Tomaszewski J., Gospodarka Polski międzywojennej 1918-1923, t. I: W dobie inflacji 1918-1923, Warszawa 1967.

Leczyk M., Druga Rzeczpospolita 1918-1939. Społeczeństwo. Gospodarka. Kultura. Polityka, Warszawa 2006.

Lundgreen-Nielsen K., Wielkie mocarstwa a Polska 1918-1919, „Niepodległość” 1981, t. XIV, s. $27-43$.

Morawski W., Dzieje gospodarcze Polski, wyd. 2, Warszawa 2011.

Morawski W., Od marki do złotego. Historia finansów Drugiej Rzeczypospolitej, Warszawa 2008.

Mucha K.W., Parlament Polski w opinii Józefa Pitsudskiego 1918-1930, „Acta Universitatis Lodziensis. Folia Historica” 2001, t. LXXI, s. 27-46.

Nowik G., Odrodzenie Rzeczypospolitej w myśli politycznej Józefa Piłsudskiego 1918-1922, cz. 1: Sprawy wewnętrzne, Warszawa 2017.

Polska odrodzona 1918-1939. Państwo, społeczeństwo, kultura, red. J. Tomicki, Warszawa 1982.

Polski Garibaldi, „Niepodległość” 1986, t. XIX, s. 228-229.

Pajewski J., Budowa Drugiej Rzeczypospolitej 1918-1926, wyd. 2, Poznań 2007.

Pajewski J., Odbudowa państwa polskiego 1914-1918, Warszawa 1978.

Pobóg-Malinowski W., Najnowsza historia polityczna Polski 1864-1945, Londyn 1956.

Próchnik A., Pierwsze piętnastolecie Polski niepodlegtej (1918-1933), Warszawa 1983.

Rakowski J., Gospodarcze zaplecze wojny polsko-bolszewickiej, „Niepodległość” 1992, t. XXV, s. $233-238$.

Skwarczyński S., Rozważania ideologiczne, „Niepodległość” 1976, t. X.

Suleja W., Józef Pitsudski, Wrocław 1995.

Żarnowski J., Spoteczeństwo Drugiej Rzeczpospolitej 1918-1939, Warszawa 1973.

Bi g r a m: Jerzy Gaul - dr hab., profesor nadzwyczajny w Archiwum Głównym Akt Dawnych w Warszawie. Zainteresowania badawcze: historia XIX i XX w., kontakty austriacko-polskie, polonika, I wojna światowa, Józef Piłsudski. Ostatnie publikacje: Józef Piłsudski. Źródła $z$ lat 1914-1918 w Austriackim Archiwum Państwowym w Wiedniu, t. I: Archiwum Wojny, t. II: Archiwum Ogólne Administracji, Archiwum Domu, Dworu i Państwa (2015-2017); Czarno-żótty miraż. Sprawa Józefa Pitsudskiego w monarchii habsburskiej 1896-1918 (2018). E-mail: jerzygaul@hoga.pl. 